\title{
PROCESS OPTIMIZATION OF DRY BATCH ANAEROBIC DIGESTION OF MUNICIPAL SOLID WASTE
}

\author{
Jeanger P. Juanga \\ University of Kalmar, Kalmar, Sweden
}

\begin{abstract}
Optimizing anaerobic digestion aims to maximize organic waste stabilization at short digestion period with higher biogas production. This paper presents different strategies to optimize the anaerobic digestion of organic fraction of municipal solid waste in combined process in which early flushing and microaeration were conducted during pre-stage. Also, the influence of substrate particle size reduction and the advantage of thermophilic system over mesophilic in the overall digestion process are presented. Additionally, an attempt was taken to employ sequential staging concept by using a mature (old) reactor which underwent a combined digestion process. Importantly, process evaluation between an optimized combined process and sequential staging concept were evaluated with the main objective of optimizing the process. Process efficiency evaluation was based on biochemical methane potential (BMP) test. The overall result suggest that the combined anaerobic digestion process can be optimized by conducting shorter duration of pre-stage at reduced volume of flushing water with microearation, under thermophilic condition at reduced substrate particle size of $30 \mathrm{~mm}$. Nevertheless, the sequential staging concept offers an improved operation over the combined anaerobic digestion wherein the higher specific methane yield of $11.9 \mathrm{~L} \mathrm{CH}_{4} / \mathrm{kg} \mathrm{VS}$.day was achieved. Improved waste stabilization with $86 \%$ and $79 \%$ mass and volume reduction which corresponds to $84 \%$ process efficiency was obtained by sequential staging process.
\end{abstract}

\section{KEYWORDS}

Anaerobic digestion; Biogas; Leachate; Microaeration; Solid waste.

\section{INTRODUCTION}

Direct dumping of municipal solid waste (MSW) in uncontrolled disposal system is a prevalent practice in most developing countries in Asia. The continuous practice of this system would apparently lead to serious environmental problems, health hazards and welfare loss. The problem on diminishing land for MSW disposal along with the increasing waste generation and the depletion of fossil fuels have fostered the need to utilize and transform the waste into usable resources. Thus, biological pre-treatment of solid waste prior to landfill by anaerobic digestion process is considered as an attractive technology and is potential in Asian countries because of its suitable waste characteristics. The generation and composition of MSW stream in Asian cities is almost similar which consists of high fraction of organic waste with high moisture content [1].

Anaerobic digestion of solid waste can be classified into variety of categories based on solid content, feeding modes, stages of operation, and type of waste. This study features the dry 
digestion technology of MSW in batch system. In order to shorten the overall digestion duration with maximum process efficiency, the process optimization needs further investigation especially during the start-up stage [2]. The leaching experiment on organic fraction of MSW showed that flushing the waste bed enhanced hydrolysis and acidification and the generated leachate can be used for cross-recirculation [3]. Moreover, the application of microaeration prior to methanization enhanced the hydrolysis rate of carbohydrates and proteins and this could enhance the anaerobic digestion process [4, 5]. This paper presents different strategies to optimize anaerobic digestion of organic fraction of MSW in combined process in which early flushing and microaeration were conducted during pre-stage. Additionally, an attempt was taken to employ sequential staging concept by using a mature (old) reactor which underwent a combined digestion process. Importantly, process evaluation between an optimized combined process and sequential staging concept were evaluated with the main objective of optimizing the process. Moreover, process efficiency evaluation based on biochemical methane potential (BMP) test was performed.

\section{METHODOLOGY}

\subsection{Equipment}

This study was performed in pilot scale anaerobic digesters with a total volume of $375 \mathrm{~L}$. The three reactors used in this experiment were equipped with top removable cover for waste loading and unloading in each batch. An optimum mesophilic $\left(37^{\circ} \mathrm{C}\right)$ and thermophilic $\left(55^{\circ} \mathrm{C}\right)$ conditions were maintained by a digital temperature controller wherein hot water from water bath was pumped into the water jacket. Air compressor was used to provide aeration/microaeration into the waste bed. The application of microaeration (limited amount of oxygen supplied in anaerobic zone) was viewed that could increase the hydrolysis rate thereby improving pre-stage performance. Each reactor is equipped with leachate recirculation system. The flushed leachate trickled through the waste and collected to the same storage tank by gravitational force. The volume of biogas produced was measured using drum type gas meter.

\subsection{Feedstock preparation and collection}

The substrate used in this study was collected from the vegetable market in Rangsit (Thailand). The collected waste was manually sorted to remove bulky and inorganic fractions and was subjected to size reduction by using a mechanical shredder. Representative waste samples were taken for solid analysis. For better process comparison, the waste loaded into the three digesters maintains similar characteristics in terms of average moisture content (MC) of $90 \%$, total solids (TS) of $10 \%$ and volatile solids (VS) of $79 \%$. The shredded waste was loaded into the reactors together with bamboo cutlets (10\% volume of loaded waste) as bulking agent to create void space to facilitate the flow and distribution of flushing water and microaeration/aeration throughout the waste bed. At the end of the process, bamboo cutlets were manually separated from the digested waste and the waste was subjected for solid analysis.

\subsection{Process Features}

\subsubsection{Combined anaerobic digestion process}

Fresh market waste was loaded into the reactors and flushed with tap water to produce leachate. The purpose of flushing was to leach out pollutant in order to reduce the constraint 
of high organic load from the waste bed. Figure 1 illustrates the three stages involved in combined anaerobic digestion process.

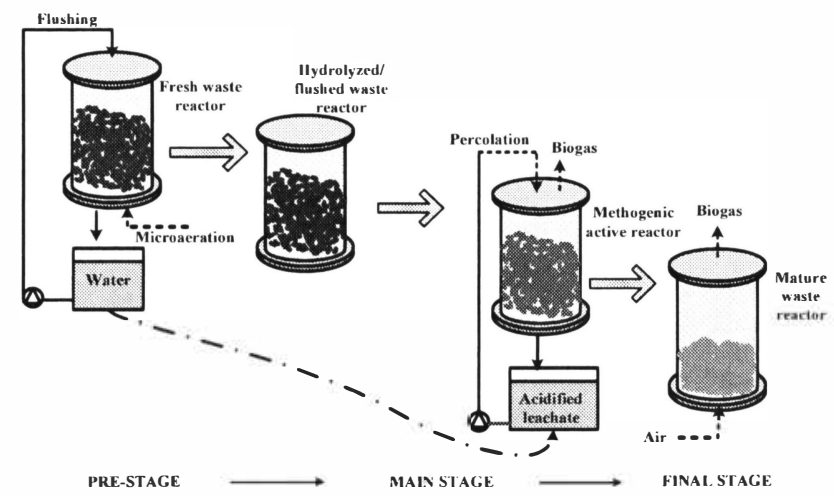

Figure 1. Combined anaerobic digestion process.

\subsubsection{Sequential batch anaerobic digestion process}

This concept was employed to compare the optimized combined anaerobic digestion process in terms of overall process efficiency. In sequential batch digestion, the mature waste reactor which underwent a complete combined digestion process and is exhausted of its methane production was coupled with freshly loaded reactor for leachate cross-recirculation (Figure 2) to provide moisture, inoculum, nutrient, and buffer necessary for the start-up of methanogenic phase. Volatile organic compounds formed during start-up were removed via leachate recycle to the mature reactor for conversion to methane and carbon dioxide. After start-up, the freshly loaded reactor becomes an active methanogenic reactor and was maintained by direct leachate recirculation $[6,7]$. The process was ended when the biogas produced decreased significantly.

\subsection{Experimental run}

This study was conducted in two runs, run 1 dealt with process optimization of combined anaerobic digestion process under two stages. Stage 1 involves process optimization by varying flushing mechanisms and the application mciroaeration during pre-stage under mesophilic condition using $60 \mathrm{~mm}$ substrate. In stage 2, the optimization process was studied by using smaller particle size of $30 \mathrm{~mm}$ under mesophilic and thermophilic conditions at shorter pre-stage duration. 


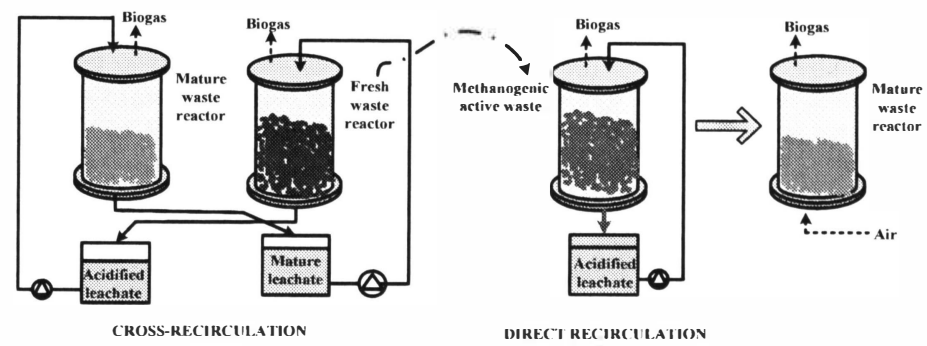

Figure 2. Sequential batch anaerobic digestion process.

Run 2 employs a mature reactor generated from an optimized combined digestion process coupled with a newly loaded reactor ( fresh waste reactor) for leachate cross-recirculation. The cross-recirculation was only stopped when the fresh reactor reached an active methanogenic phase and direct leachate recirculation was performed. The process details conducted in two runs are described in Figure 3.

Pre-stage was performed at varying conditions. Daily water replacement during pre-stage enhanced leaching [3]. In this study (Run 1, stage 1), daily water replacement was applied in reactor $1(\mathrm{R} 1)$, whereas in reactor $2(\mathrm{R} 2)$ and $3(\mathrm{R} 3)$, water was replaced after day 1 and on day 3 of operation. As a result, a total of $1000 \mathrm{~L}$ water $(48.8 \mathrm{~L} / \mathrm{kg}$ TS) was used for R 1 , and only $600 \mathrm{~L}$ water $(29.3 \mathrm{~L} / \mathrm{kg} \mathrm{TS})$ was used for R2 and R3. Flushing was carried out at a rate of $5 \mathrm{~L} / \mathrm{min}$ for $4 \mathrm{~h}$ run $/ 4 \mathrm{~h}$ stop. In R3, five days of microaeration was provided at a rate of 1 $\mathrm{L} / \mathrm{min}(0.4 \mathrm{~L} / \mathrm{kg} \mathrm{h})$ for $2 \mathrm{~h}$ run $/ 4 \mathrm{~h}$ stop; while in $\mathrm{R} 1$ and $\mathrm{R} 2$, microaeration was not applied. In stage 2 of Run 1, the flushing operation and microaeration was continuously examined under different temperature conditions (mesophilic and thermophilic) and reduced substrate particle size of $30 \mathrm{~mm}$.

Following pre-stage in Run 1, new condition was provided in order to enhance the start-up of methane phase. The $\mathrm{pH}$ of the system was adjusted to around 7.0 and was followed by inoculum addition. Mixture of cow dung, stabilized/digested waste and anaerobic sludge was used as seeding material totally accounting for $16 \%$ VS of the loaded waste. Percolation was performed for two days to distribute inoculums throughout the waste bed. Different strategies were applied for three digesters in stage 1 of Run 1 . In R 1 and R3, leachate percolation was only practiced by the time the reactor shifted to active methane phase and that was on day 40 and 30, respectively. However, in R2 leachate percolation was not provided. Pre-stage leachate was percolated at rate of $0.2 \mathrm{~L} / \mathrm{min}$ for $4 \mathrm{~h} \mathrm{run} / 4 \mathrm{~h}$ stop and replaced in batch mode. At the end of methane phase, the waste bed was flushed with fresh air for one day before unloading the digester. However, the R3 (Run 1, stage 2) which showed an optimized process among the other reactors was continuously operated and used as a mature reactor to study the sequential staging process. After unloading R2 (stage 2), it was loaded with $200 \mathrm{~kg}$ of fresh waste and coupled with R3 (matured reactor) to perform the sequential staging process. 


\begin{tabular}{|c|c|c|c|}
\hline \multirow[b]{2}{*}{$\begin{array}{c}\text { Run 1 } \\
\text { (Stage 1) }\end{array}$} & Reactor 1 (R1) & Reactor $2(\mathrm{R} 2)$ & Reactor 3 (R.3) \\
\hline & 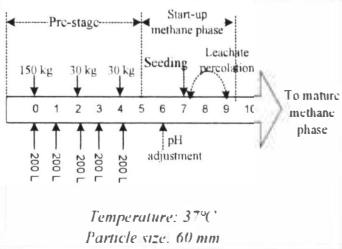 & 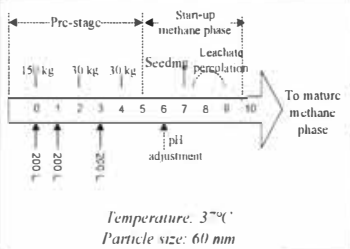 & 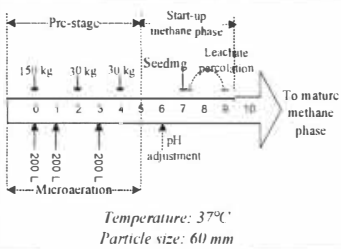 \\
\hline $\begin{array}{c}\text { Run 1 } \\
\text { (Stage 2) }\end{array}$ & 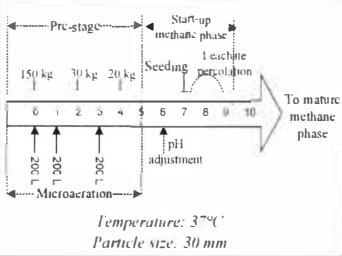 & 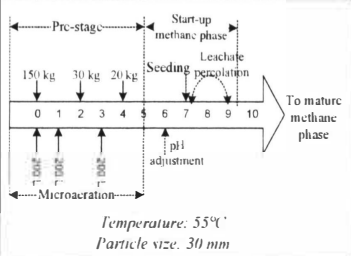 & 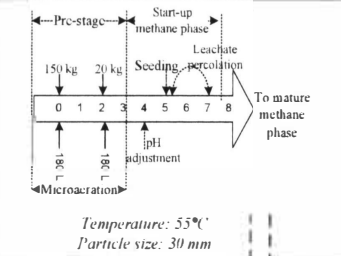 \\
\hline Run 2 & & $\begin{array}{c}\text { Coupled with mature } \\
\begin{array}{c}\text { waste riactor (R3) for } \\
\text { cross-recirculation }\end{array}\end{array}$ & $\begin{array}{l}\text { RJ (Wature naste reactor) } \\
\text { carried into Run } 2 \text { or }\end{array}$ \\
\hline
\end{tabular}

Figure 3. Process mechanism during pre-stage optimization.

\section{RESULTS AND DISCUSSIONS}

\subsection{Pre-stage performance}

In three digesters (Run 1, stage 1), highest DOC concentration $(4 \mathrm{~g} / \mathrm{L})$ was noted in the first day of flushing. The result showed that DOC concentration in daily leachate reduced sharply with run time to around $1.5 \mathrm{~g} / \mathrm{L}$ in five days. Flushing the waste bed using $1000 \mathrm{~L}$ of water could generate more pollutant load (DOC $=140 \mathrm{~g} / \mathrm{kg} \mathrm{TS} ; \mathrm{TKN}=18 \mathrm{~g} / \mathrm{kg} \mathrm{TS}$ ) compared to the reactors flushed with $600 \mathrm{~L}$ (DOC $=128 \mathrm{~g} / \mathrm{kg}$ TS; TKN $=15 \mathrm{~g} / \mathrm{kg}$ TS. The importance of microaeration during this stage showed an equivocal result. Moreover, comparison of DOC and DOC equivalent of TVFA (Table l) exhibited that over half of the soluble organic carbon in leachate was acidified into VFA. This showed that acidification was strong over hydrolysis.

Run 1, stage 2 operation, described the importance of reducing substrate particle size. In this case, R3 of stage 1 and R1 of stage 2 can be compared wherein 60 and $30 \mathrm{~mm}$ substrate particle size was used, respectively. More DOC load and VFA fraction in DOC can be generated by a reduced particle size. It can be concluded therefore that reducing substrate particle size enhances pre-stage performance. The importance of increasing reaction temperature from $37^{\circ} \mathrm{C}$ to $55^{\circ} \mathrm{C}$ could generate more DOC and VFA fraction in DOC as can be seen in Table 1. This emphasizes the positive influence of increasing temperature in enhancing pre-stage performance. The importance of reducing the amount of flushing water from $600 \mathrm{~L}$ to $360 \mathrm{~L}$ does not exhibit a negative effect in pre-stage performance instead it does enhance the process since it can limit the dilution of leachate concentration. The high fraction of VFA in leachate favored the proposal of feeding it back into the digester during methane phase by leachate percolation. Early extraction of VFA in pre-stage leachate would prevent imbalance between acidogenesis and methanogenesis in methane phase which was normally considered to cause instability in high-solid digestion system [8]. Lower 
concentration of VFA at the end of pre-stage suggested that strict separation of acidogenesis and methanogenesis could not be achieved at this point and it would be better to shift the reactor to methane stage. In this regard, $\mathrm{pH}$ adjustment and inoculum addition was performed after pre-stage in Run 1.

Table 1. Load of DOC and DOC equivalent of VFA in pre-stage leachate.

\begin{tabular}{|c|c|c|c|}
\hline \multirow[b]{2}{*}{ Run 1, stage 1} & \multicolumn{3}{|c|}{$37^{\circ} \mathrm{C} ; 60 \mathrm{~mm}$} \\
\hline & RI ( $1000 \mathrm{~L}$ water) & R2 (600 L water) & $\begin{array}{l}\text { R3 ( } 600 \mathrm{~L} \text { water; } \\
\text { with microaeration) }\end{array}$ \\
\hline DOC & 140 & 128 & 129 \\
\hline DOC equivalent of TVFA & 83 & 80 & 88 \\
\hline \multirow[b]{2}{*}{ Run 1, stage 2} & $37^{\circ} \mathrm{C} ; 30 \mathrm{~mm}$ & \multicolumn{2}{|c|}{$55^{\circ} \mathrm{C} ; 30 \mathrm{~mm}$} \\
\hline & RI (600 L; with microaeration) & R2 (600 L: with microaeration) & $\begin{array}{l}\text { R3 (360 L: with } \\
\text { microaeration) }\end{array}$ \\
\hline DOC & 169 & 181 & 188 \\
\hline DOC equivalent of TVFA & 147 & 167 & 158 \\
\hline
\end{tabular}

Note: unit expressed in $\mathrm{g} \mathrm{C/kg} \mathrm{TS} \mathrm{(DOC} \mathrm{and} \mathrm{DOC} \mathrm{equivalent} \mathrm{of} \mathrm{TVFA)}$

\subsection{Methane stage performance}

\subsubsection{Run 1: stage 1}

Figure 4 shows the cumulative biogas production in methane stage. During start-up, it was observed the biogas production was low and methane content increased slowly to $50 \%$. The system was successfully started-up after 25 days. Gas production rate in R3 was higher than $\mathrm{R} 1$ and $\mathrm{R} 2$. The possible explanation was due to early microaeration in pre-stage which might have resulted in better hydrolysis/acidifcation during start-up of methanization period. Different behaviors could be observed after start-up, in R3, it was observed that cumulative gas production increased immediately after lag phase. Leachate percolation during active methane phase was conducted by batch. Regarding the cumulative gas production, R3 gained the highest biogas production of about $4800 \mathrm{~L}(256 \mathrm{~L} / \mathrm{kg}$ TS) after 60 days of operation when compared to R1 $(2300 \mathrm{~L})$ and R2 $(2700 \mathrm{~L})$. Thus, it can be suggested that though microaeration showed an equivocal results during pre-stage performance, it does enhance methane phase. The importance of leachate percolation during methane phase in R3 enhances biogas production when compared to $\mathrm{R} 2$ without leachate percolation.

\subsubsection{Run 1: stage 2}

The importance of reducing particle size from 60 to $30 \mathrm{~mm}$ does not only enhance pre-stage performance but also in methane phase. It was observed in this study that digestion using 60 $\mathrm{mm}$ substrate particle size is able to produce approximately $4800 \mathrm{~L}$ of biogas after 60 days of operation, while this much of biogas can be produced by using $30 \mathrm{~mm}$ substrate after 47 days only.

This showed that reducing substrate particle size is able to shorten digestion time at enhanced process. Moreover, higher methane concentration can be obtained at reduced particle size. Moreover, the importance of increasing temperature from $37^{\circ} \mathrm{C}$ to $55^{\circ} \mathrm{C}$ under combined anaerobic digestion concept was verified. The result showed that after 47 days of operation, around $4800 \mathrm{~L}$ of biogas was produced by mesophilic reactor while thermophilic reactor produced higher biogas production of $5400 \mathrm{~L}$ (Figure 5). 
Kalmar ECO-TECH '07

KALMAR, SWEDEN, November 26-28, 2007

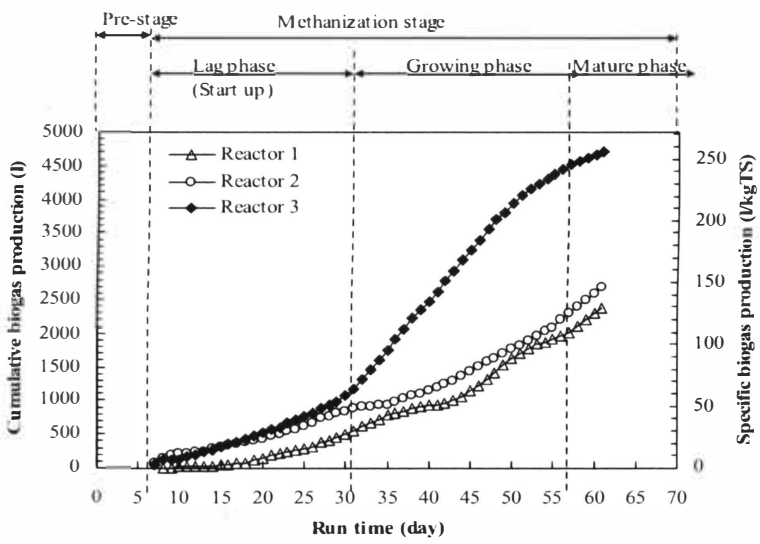

Figure 4. Cumulative biogas production for Run I, stage I (RI, R3: leachate percolation on day 40, 30; R2: no leachate percolation).

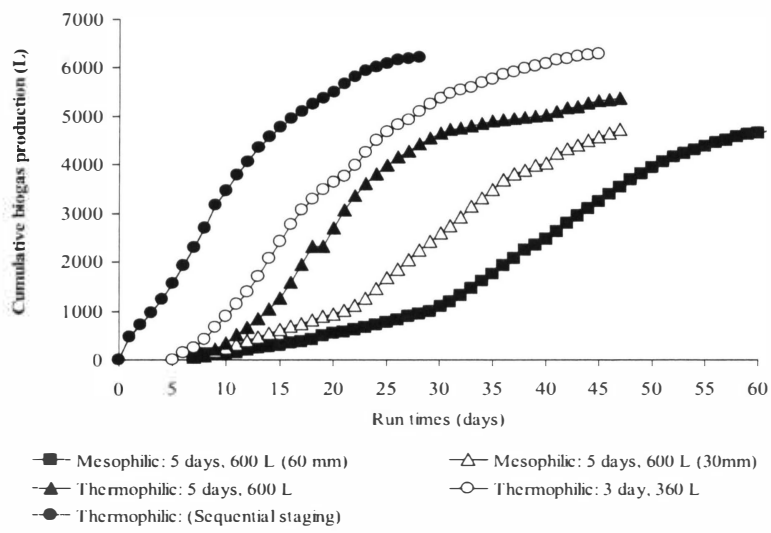

Figure 5. Comparison of cumulative biogas production from combined anaerobic digestion and sequential staging concept. 
The importance of flushing the reactor at less volume of water was highlighted by R2 and R3 (Run 1, stage 2). A positive shift of methane performance due to less volume of flushing water provides added benefits. A lag phase period of 5 days (after pre-stage) was exhibited by both reactors. However, an active methane phase was obtained earlier by R3. In this case shortening pre-stage operation in combined process does not negatively affiect methane phase wherein a likely improved methane concentration can be observed.

The commencement of acidified leachate percolation during active methane phase exhibits a rapid increase of biogas in all studied reactors which indicates that leachate percolation enhances leachate contact with the waste which have a positive influence in the process [9]. After 47 days of operation R2 produced a total of $5300 \mathrm{~L}(310 \mathrm{~L} \mathrm{~kg} / \mathrm{TS})$ of biogas while R3 generates $6300 \mathrm{~L}(332 \mathrm{~L} \mathrm{~kg} / \mathrm{TS})$ of biogas after 45 days. The operation of reactors can be stopped after 30 days because of insignificant increase of biogas. The result of experiment showed that R3 operation ( 3 days, $360 \mathrm{~L}$ water) was better than R2 (5 days, $600 \mathrm{~L}$ water) during pre-stage and methane stage. A possible shift of R3 performance due to pre-stage operation offiers advantages such as less volume of flushing water with improved pre-stage operation and does not negatively affiect methane phase but it may possibly enhance. Higher specific methane yield was obtained by $\mathrm{R} 3\left(7.2 \mathrm{~L} \mathrm{CH}_{4} / \mathrm{kg}\right.$ VS.day) compared to $\mathrm{R} 2(6.8 \mathrm{~L}$ $\mathrm{CH}_{4} / \mathrm{kg}$ VS.day) (Table 2).

Table 2. Assessment of methane phase and overall process.

\begin{tabular}{|c|c|c|c|c|c|c|}
\hline \multicolumn{3}{|c|}{ Run no/operating parameters } & $\begin{array}{l}\% \text { Mass } \\
\text { reduction }\end{array}$ & $\begin{array}{l}\% \text { Volume } \\
\text { reduction }\end{array}$ & $\begin{array}{c}\text { Methane yield } \\
\text { ( } \mathrm{L} \mathrm{CH}_{4} / \mathrm{kg} \text { VS.day) }\end{array}$ & $\begin{array}{c}\text { Process efficiency } \\
(\%)\end{array}$ \\
\hline \multirow{6}{*}{ Run I } & \multirow{3}{*}{$\begin{array}{c}\text { Stage } 1 \\
\left(37^{\circ} \mathrm{C} ; 60\right. \\
\mathrm{mm})\end{array}$} & RI (7 days; 1000 L) & 60 & + & 2.4 & 33.0 \\
\hline & & R2 (5 days; 600 L) & 63 & - & 2.6 & 38.0 \\
\hline & & $\begin{array}{l}\text { R3 (5 days; } 600 \mathrm{~L} \text {; } \\
\text { microaeration }\end{array}$ & 63 & 40 & 4.8 & 66.0 \\
\hline & $\begin{array}{c}\text { Stage } 2 \\
\left(37^{\circ} \mathrm{C} ; 30 \mathrm{~mm}\right.\end{array}$ & $\begin{array}{l}\mathrm{RI}(5 \text { days; } 600 \mathrm{~L} \text {; } \\
\text { microaeration) }\end{array}$ & 66 & 47 & 6.1 & 71.4 \\
\hline & \multirow{2}{*}{$\begin{array}{c}\text { Stage } 2 \\
\left(55^{\circ} \mathrm{C} ; 30 \mathrm{~mm}\right.\end{array}$} & $\begin{array}{l}\mathrm{R} 2 \text { ( } 5 \text { days; } 600 \mathrm{~L} \text {; } \\
\text { microearation) }\end{array}$ & 74 & 58 & 6.8 & 80.0 \\
\hline & & $\begin{array}{l}\text { R3 (3 days; } 360 \mathrm{~L} \text {; } \\
\text { microaeration) }\end{array}$ & 84 & 74 & 7.2 & 80.4 \\
\hline Run 2 & $55^{\circ} \mathrm{C} ; 30 \mathrm{~mm}$ & R2 (sequential staging) & 86 & 79 & 11.9 & 84.0 \\
\hline
\end{tabular}

Note: Process efficiency was calculated based on the BMP test result of $400 \mathrm{~L} \mathrm{CH}_{4} / \mathrm{kg} \mathrm{VS}$.

\subsubsection{Run 2}

It should be noted that R3 from Run 1 (stage 2) operation exhibited an optimum process efficiency compared to other reactors in Run 1 . In this case, R3 was continuously operated for 2 months before it was coupled with R2 (newly loaded) to conduct the sequential staging anaerobic digestion process. Importantly, pre-stage operation was not performed in R2. After the two reactors were coupled, an active methane phase was rapidly exhibited by new reactor (R2) when compared to previous run. The methane concentration in both reactors increased and was stable to around $50 \%$ after 4 days of operation. Also, the $\mathrm{pH}$ of $\mathrm{R} 2$ started at 5.6 and increase to $>6.5$ after 4 days and this would indicate that the system was fully started-up. The said reactors were uncoupled and direct leachate recirculation on R2 commenced on day 10 . During the commencement of direct recirculation, the $\mathrm{pH}$ remained above 7 and stabilized at a value of 7.7 during the entire run. The observed decreasing trend of DOC and VFA in leachate accompanied with the increase of biogas may indicate a balance system. The reduction of VFA or DOC concentration from the waste bed may be attributed by removal 
through leachate recycle and enhanced development of methanogenic microbe population. Moreover, $\mathrm{NH}_{4}-\mathrm{N}$ concentration did not increase significantly instead the concentration leveled off at $1 \mathrm{~g} / \mathrm{L}$. Thus, this process is very resilient in which the presence or accumulation of inhibitory substances did not establish and can be better controlled at proper performance evaluation.

\subsection{Process efficiency}

The methane yield in pilot scale digesters was compared to lab-scale BMP test to verify the process conversion efficiency. Methane yield was based from \% VS destruction for it offiers better representation in the actual process performance [10]. BMP test of the fresh waste generates $400 \mathrm{~L} \mathrm{CH}_{4} / \mathrm{kg}$ VS. Table 2 represents the overall assessment of methane phase. It can be suggested that flushing the waste bed using $600 \mathrm{~L}$ of water with the application of microaeration during pre-stage plus the practice of leachate percolation are the mechanism that enhanced the combined process. Moreover, overall process efficiency of using $30 \mathrm{~mm}$ particle size is higher than using $60 \mathrm{~mm}$ which corresponds to $66 \%$ and $71.4 \%$ respectively. Besides, the overall process efficiency even improved when the digestion was conducted under thermophilic condition rather than mesophilic which improves the process efficiency up to $80 \%$. The importance of pre-stage flushing using $360 \mathrm{~L}$ of water over $600 \mathrm{~L}$ also improved the process wherein methane yield improves from 6.8 to $7.2 \mathrm{~L} \mathrm{CH}_{4} / \mathrm{kg}$ VS.day. The higher specific methane yield of $7.2 \mathrm{~L} \mathrm{CH}_{4} / \mathrm{kg}$ VS.day was produced by R3 (Run 1, stage 2) after 45 days of operation indicates that shortening pre-stage under reduced volume of flushing water does not negatively affect the overall process. In this regard, an improved methane generation, mass and volume reduction was achieved by a reduced operation with less flushing water. However, among them, better result was displayed by R2 (Run 2). Improved digester performance in terms of waste stabilization was achieved. Nonetheless, $84 \%$ process efficiency was obtained after 28 days of operation with higher specific methane yield of 11.9 $\mathrm{L} \mathrm{CH}_{4} / \mathrm{kg}$ VS.day).

\section{CONCLUSIONS}

The results showed that pre-stage flushing operation for 3 days $(1.8 \mathrm{~L} / \mathrm{kg})$ is more preferable than 7 days $(4.7 \mathrm{~L} / \mathrm{kg})$ or 5 days $(3 \mathrm{~L} / \mathrm{kg})$. Reduced substrate particle size of $30 \mathrm{~mm}$ exhibited better process performance over $60 \mathrm{~mm}$. The concentrated leachate obtained at pre-stage showed beneficial effect during methane phase leachate percolation in improving biogas production. This signifies that reducing pre-stage operation and volume of flushing water does not negatively affiect the process performance. But it enhances the maximum removal of organics from waste bed which is beneficial in optimizing the process in combined anaerobic digestion. Nevertheless, leachate cross-recirculation between the old and new reactors directly without conducting pre-stage operation optimizes the overall digestion process. The sequential staging concept offiers an improved operation over the combined anaerobic digestion wherein the specific methane yield of $11.9 \mathrm{~L} \mathrm{CH}_{4} / \mathrm{kg}$ VS.day and $7.2 \mathrm{~L} \mathrm{CH}_{4} / \mathrm{kg}$ VS.day was achieved, respectively. Improved waste stabilization with $86 \%$ and $79 \%$ mass and volume reduction was achieved, respectively with higher methane yield of $334 \mathrm{~L} \mathrm{CH}_{4} / \mathrm{kg} \mathrm{VS}$ which is equivalent to $84 \%$ process efficiency was obtained.

\section{ACKNOWLEDGMENTS}

The authors wish to convey their gratitude to the Swedish International Cooperation Development Agency (SIDA) for generously supporting this research in financial aspects. 
This research is part of the Sustainable Solid Waste Landfill Management in Asia under the Asian Regional Research Program on Environmental Technology (ARRPET).

\section{REFERENCES}

[1] Visvanathan, C., Tränkler, J., Chiemchaisri, C., Basnayake, B.F.A., Gongming, Z., 2004. Municipal Solid Waste Management in Asia: Asian Regional research Program on Environmental Technology (ARRPET). ISBN: 974-417-258-1.

[2] Meisgeier, N., Bidlingmaier, W., Kraft, E., Meisgeier, G.., 2003. The Shortening and Optimization of the Start up Stage-A Great Challenge for anaerobic digestion technology of the future. In: Pullammanappallil, P., McComb, A., Diaz, L. \& Bidlingmaeir, W. (eds): Proceedings of the Fourth International Conference of ORBIT 2003 Association on Biological Proceedings of Organics: Advances for a Sustainable Society (Part 2), Perth, Australia, pp. 10-14 (Poster presentation). ISBN: 3-935974-04-3. Publisher, ORBIT Association, Perth, Australia.

[3] Dayanthi, W.K.C.N., Visvanathan, C., Tränkler, J., Kuruparan, P., 2004. Pretreatment of domestic solid waste by enhanced leaching. In: Hanashima, M. (eds): Proceedings of the $3^{\text {rd }}$ Asian Pacific Landfill Symposium (APLAS): Landfill technology and management for sustainable society, pp. 232-239, October 27-29, 2004, Kitakyusu, Japan. Published by Japan Society of Waste Management Experts (JSWME), Tokyo, Japan.

[4] Pirt, S.J., Lee, Y.K., 1983. Enhancement of methanogenesis by traces of oxygen in bacterial digestion of biomass. FEMS Microbiol. Lett. 18, 61-63.

[5] Johansen, J.E., Bakke, R., 2006. Enhancing hydrolysis with microaeration. Water Science and Technology, 53 (8), 43-50.

[6] Dallheimer, F., Heerenklage, J., Stegmenn, R., 1999. A multichamber anaerobic dry fermentation plant for the pretreatment of residual municipal solid waste. Proceeding $7^{\text {th }}$ Intern. Landfill Symp. Sardinia 99, CISA, Italy.

[7] Chynoweth, D.P., Sifontes, J.R., Teixeira, A.A., 2003. Sequential batch anaerobic composting of municipal and space mission waste and bioenergy crops. (Presented in ORBIT conference,

Perth, Australia):http://www.agen.ufl.edu/ chyn/download/SebacORBIT.doc.

[8] Mata-Alvarez, J., 2003. Biomethanization of the organic fraction of municipal solid waste. IWA publishing. ISBN: 1900222140.

[9] Warith, M.A., Smolkin, P.A., Caldwell, J.G.., 2001. Effect of leachate recirculation on enhancement of biological degradation of solid waste: case study. Practice periodical of hazardous, toxic, and radioactive waste management.

[10] Teixeira, A.A., Chynoweth, D.P., Owens, J.M., Rich, E.R., Dedrick, A.L., Haley, P.J., 2004. Prototype space mission SEBAC biological solid waste management system. $34^{\text {th }}$ international conference on environmental systems (ICES). Paper 2004-ICES-098. http://faculty.abe.ufl.edu/ chyn/download/Publications_DC/Refereed/2004ICES_SEBAC2004.pdf. 